\title{
Direct Bilirubin to Bilirubin Ratio Measurement
}

National Cancer Institute

\section{Source}

National Cancer Institute. Direct Bilirubin to Bilirubin Ratio Measurement. NCI Thesaurus.

Code C158226.

The determination of the ratio of direct bilirubin compared to total bilirubin present in a sample. The measurement may be expressed as a ratio or percentage. 